scribed by the Minister of Housing and Local Government or the Secretary of State for Scotland. It also provides that on and after the appointed day every industrial building in which fuel is consumed for space heating shall be similarly thermally insulated in accordance with minimum standards prescribed by the Minister, and that it shall be the duty of the local authority to enforce the provisions of the Act. The Act will not apply to any industrial building where thermal insulation would result in no economy in the consumption of fuel, and the Minister, who is responsible for determining whether or not such an economy would result, is also empowered to exempt, by order, any industrial building or class of industrial buildings from the provisions of the Act. Mr. Nabarro, in asking leave to introduce the Bill, said that the National Industrial Fuel Efficiency Service estimated that up to 6 million tons of coalequivalent were lost every year as a result of failure to insulate thermally industrial buildings in Britain. $\mathrm{He}$ claimed that his Bill was complementary to the clean air policy, which itself was essentially one of fuel efficiency.

\section{The Diploma in Technology}

The National Council for Technological Awards has announced that the following courses now in progress have been recognized as leading to the Diploma in Technology. Full-time courses : Battersea Polytechnic (applied chemistry, chemical, mechanical, civil and electrical engineering, metallurgy); Sandwich courses : Acton Technical College (applied chemistry, applied physics, electrical and mechanical engineering); Battersea Polytechnic (applied chemistry, chemical, electrical and mechanical engineering, metallurgy); Birmingham College of Technology (applied chemistry, chemical technology, applied physics, electrical engineering and mechanical and production engineering) ; Cardiff College of Technology and Commerce (mechanical/production engineering; Woolwich Polytechnic (electrical and mechanical engineering). The Council has also approved the following new courses: Sandwich courses : Battersea Polytechnic (civil engineering and physics) ; Birmingham College of Technology (technological mathematics) ; Chelsea Polytechnic (applicable mathematics); and Woolwich Polytechnic (mathematics applied to engineering).

In making this announcement, Lord Hives, the chairman of the Council, pointed out that two of the colleges at which courses have been recognized, namely, Acton Technical College and Woolwich Polytechnic, are not colleges of advanced technology; he hoped that this would be a source of encouragement to all technical colleges. The National Council for Technological Awards, with its two boards of studies (in engineering and technologies other than ongineering), was set up by the Minister of Education as an independent self-governing body to create and administer national technological awards of high standing available to students in technical colleges who successfully complete approved courses. The Council has opened new offices at 9 Cavendish Square, London, W.1.

\section{Insignia Awards in Technology}

InsIgnia Awards of Technology of the City and Guilds of London Institute (C.G.I.A.) have been conferred, as Special Annual Awards, on the follow. ing: F. Scholefield, technical adviser to the Dye- stuffs Office of the Board of 'Trade and formerly head of the Department of Textile Chemistry, Manchester College of Technology (chemical industries - manufacture of dyes) ; F. Limb, factory manager, Ericsson Telephones, Ltd. (electrical industries-telecommunications); J. Loxham, managing director of the Sigma Instrument Co., Ltd., Letchworth (mechanical industries-precision engineering); E. Isles, chairman of the executive board of directors of the British Cotton and Wool Dyers Association (textile industries -textile dyeing).

In addition to their normal Insignia Awards in Technology, the Council of the City and Guilds of London Institute makes Special Annual Awards up to a maximum of five (one in each of the broad industrial groups into which, for purposes of the administration of the Award, industry is divided; namely, chemical, constructional, electrical, mechanical and textile). These are granted to selected persons of outstanding technological achievement, who by their example are an indication to candidates of the possibilities of success and accomplishment.

\section{Carlsberg-Wellcome Travelling Research Fellow- ships}

THE directors of the Carlsberg Foundation, in Copenhagen, and the Wellcome 'Trustees, in London, have decided to institute a system of CarlsbergWellcome Travelling Research Fellowships, with the object of encouraging friendly co-operation, on an exchange basis, between Danish and British research workers in any branch of the natural sciences which has a bearing upon human and animal medicine. One fellowship annually will be awarded to a candidate from the United Kingdom for a year's work in Denmark and one annually to a Danish candidate for a year's work in the United Kingdom. The stipend may range from $£ 800$ to $£ 1,200$ per annum (or the equivalent sums in Danish kroner) for wholetime research. Travelling and some incidentel expenses will be provided in addition. It is intended that the first appointments shall be made in respect of the academic year beginning in September 1957. Inquiries from candidates in the United Kingdom should be addressed to the Scientific Secretary of the Wellcome Trust, 52 Queen Anne Street, London, W.1. There is no form of application, but candidates should submit a full curriculum vitae, together with details of their research proposals and a supporting letter from a senior scientist who is familiar with their work. Completed applications must be submitted before April 30.

\section{Freshwater Fisheries Laboratory, Pitlochry}

IN the summer of 1948 a small laboratory was established near Pitlochry, Perthshire, to conduct investigations on the biology of brown trout in Scotland. This laboratory was established jointly by the North of Scotland Hydro-Electric Board and the Scottish Home Department and was called the Brown Trout Research Laboratory. Both these bodies had a direct interest in these investigations, the HydroElectric Board because the development of its projects could markedly affect brown trout fishing in Scotland, and the Scottish Home Department because, as the Government department responsible for fisheries research in Scotland, it had long been interested in developing work on brown trout. The area around Pitlochry provides a wide variety of types of freshwater and, as Pitlochry is roughly in the centre of scotland, it is a very suitable site for a laboratory 